\title{
Cognitive Dissonance \& Plagiarism: the Banality of Academic Dishonesty
}

\author{
Made Syanesti Adishesa \\ Faculty of Psychology, Atma Jaya Catholic University of Indonesia \\ syanes.adishesa@atmajaya.ac.id \\ Ferdinand Prawiro \\ Faculty of Psychology, Atma Jaya Catholic University of Indonesia \\ ferdi.prawiro@atmajaya.ac.id
}

\begin{abstract}
This study attempted to apply the hypocrisy induction principle in a real-life setting, a behavioral modification method in which cognitive dissonance was invoked in order to dissuade people from certain undesirable behavior. The aim of this experiment was testing the effect of hypocrisy induction in decreasing plagiarism among students. 136 high school students in their second year were categorized into four groups (hypocrisy, commitment only, mindful only, control), and given a task in which plagiarism was made possible. The tasks submitted by the students were given a plagiarism score using a program which matches them with online articles. Data analysis showed that the hypocrisy induction did not produce a significant effect on plagiarism. $92 \%$ of participants committed plagiarism in varying levels, indicating a banality of plagiarism in the school. The implications of these results on plagiarism prevention were discussed.
\end{abstract}

Keywords: plagiarism, hypocrisy induction, cognitive dissonance, experiment

Received 26 August 2019/Accepted 27 February 2020 @JEHCP All rights reserved

\section{Introduction}

The rapid development of technology has proven beneficial for many aspects of human lives. In the educational sector, technology has made the learning experience more engaging and appealing to students (Arda, Saehana, \& Darsikin, 20I5). Various devices designed to enhance learning have transformed teaching methods, giving birth to new ways in lesson delivery, such as e-learning and blended learning (Fitriyadi, 20/3). The government of Indonesia has also shown its support by building a national fiber-optic network to widen internet access across the country. Moreover, the creation of the Jaringan Pendidikan Nasional (National Education Network) has connected more than 3,000 education institutions (Mudiahardjo \& Donny, 2009). Data from the Indonesian Ministry of Education showed that about $50 \%$ of schools have had access to the internet since mid-2014 
(Permanasari, 20I5). More recently, the Indonesian government has also made fast internet installation in schools all over Indonesia a priority (Mediani, 20I8).

Due to the use of technology in educational settings, the role of the teacher has shifted (Amin, 2016; Ozdamli \& Asiksoy, 2016; Shelton, Archambault, \& Hale, 2017; W. Stone, 2000). Teachers who used to be perceived as the primary source of information now act as learning facilitators. Their tasks also changed, from controlling all aspects of learning to encourage students' independence, giving them choices in what to learn and how to learn it. By consequence, students were expected to be an active actor in the learning process instead of a passive receiver of information (Lai, Yeung, \& Hu, 2016). Students were encouraged to produce knowledge through course works, which require searching for information from outside sources using the internet (Fitriyadi, 20I3; Hoda, 2017).

Internet access has given students ease in acquiring information while also facilitate the tendency to cite them without proper credit to its original owner. The use of other people's ideas or works without giving appropriate attribution to the original owner is called plagiarism (Razera, 20II). Copying and pasting information from the internet allow students to obtain answers without truly comprehending their content (Burdick, 1998). Students can combine certain words without understanding, assimilate, or intellectually analyzing the concept (Igo, Bruning, \& McCrudden, 2005). This practice is incompatible with the aim of using technology in the classroom, which is to help students independently widen their horizon and learning to process information logically and critically (Hopson, Simms, \& Knezek, 200I).Thus, plagiarism threatens the very core of educational aim. Students who plagiarize are also found to be more likely to conduct ethical violations in college (Harding, Mayhew, Finelli, \& Carpenter, 2007) and in their occupation (KeithSpiegel \& Whitley, 200I).

The most commonly found form of plagiarism was copying text from books or online without citing the source (Lines, 2016). Therefore, most of the plagiarism cases can be avoided by proper citing, acknowledging the source of the material, and providing sufficient information to locate said source (Neville, 2010). However, a lot of students who committed plagiarism do not understand that copying and pasting without attribution to its source is an ethical violation (Marshall \& Garry, 2005). They perceive those acts as merely collecting information and do not have a firm understanding on the concept of intellectual 
property (Ukpebor \& Ogbebor, 2013). Moreover, students are often confused which information is available for public use and which is not. Other factors which may cause plagiarism are procrastination tendency, overly competitive attitude, and fear of failure (Heckler \& Forde, 2015; Kustiwi, 2014; Sureda-Negre, Comas-Forgas, \& Oliver-Trobat, 20I5).

Given the impacts of plagiarism, educational institutions have made various attempts to diminish the rate of plagiarism. Supervision using a program designed to detect plagiarism and heavy sanctions are two of the most common method employed by schools (Germek, 2012; Park, 2004). This is also the case in Indonesia, where most educational institutions have rules prohibiting students from dishonest behavior such as plagiarism. These systems are punitive instead of preventive in nature. Insufficient or inconsistent punishment could lead to students become more encouraged to cheat (O'Rourke, Barnes, Deaton, Fulks, Ryan, \& Rettinger, 2010; Whitley, 1998). Thus, punishment alone is not enough to address academic dishonesty.

Attempts have also been made to reduce plagiarism by instilling moral values in students. In Indonesia, for example, some religion-based educational institutions had in-depth religious values as part of their formal curriculum. Thus, moral virtues such as morality and honesty were instilled throughout the school year. However, plagiarism was still found to be rampant in such institutions (Ungusari, 2015; Zalnur, 2012). Other studies found that attempts to instill moral values and fear of repercussions have also been ineffective in changing student's attitudes and behaviors (Spear \& Miller, 20I2). However, cognitive approach has been found to have a more successful outcome in reducing plagiarism (Khotimah, Fadhli, \& Habibi, 20I7).

One of the approaches used in changing behavior is the hypocrisy induction, based on the cognitive dissonance principle. This method produced dissonance by making individuals aware of the gap between what they preach and what they actually do. The dissonance then generates a feeling of hypocrisy, which theoretically leads to behavioral change in order to reduce it (Aronson, Wilson, Akert, \& Sommers, 2016). The hypocrisy induction principle has been successfully used to change behavior before, in the context of condom usage (Aronson, Fried, \& Stone, 199I; Dickerson, Thibodeau, Aronson, \& Miller, 1992; Stone, Aronson, Crain, Winslow, \& Fried, 1994). 
The hypocrisy induction method differs from other previously mentioned methods in some respects. Firstly, the dissonance between one's cognition and one's behavior produced by the feeling of hypocrisy created an internal pressure to change said behavior. When the person persuades him/herself to change their behavior, it could lead to longer-lasting effect of attitude and behavior change (Aronson, 1999). Moreover, individuals may believe that some problems, such as plagiarism, are not theirs to solve. The feeling of hypocrisy may reduce this denial by reminding the individuals of their contribution to the problem, and thus have a responsibility in fixing it (Fried \& Aronson, 1995a).

Several studies have successfully applied hypocrisy induction as a behavioral change method, especially in the context of promoting healthy behavior (Aronson et al., 1991; Stone et al., 1994)and recycling behavior (Fried \& Aronson, 1995b). Based on those results, researches have attempted to used hypocrisy induction to reduce plagiarism before (Goldonowicz, 20l4; Vinski \& Tryon, 2009). Previous researches used self-report in obtaining student's cheating rates. Vinski \& Tryon (2009) asked students how many tests they took and the number of those tests in which they cheated. Goldonowics (2014) and Khotimah, Fadhli, \& Habibi (2017) also used a self-report questionnaire to assess student's cheating behavior. While participants were guaranteed the anonymity and confidentiality of their data, it is difficult to accurately measure plagiarism using self-report measurement. This indicates a need to measure the impact of hypocrisy induction using an objective assessment of the plagiarism rate.

This study replicated the previous one conducted by Goldonowicz (20I4), which involved the use of hypocrisy induction in reducing plagiarism among high school students. The hypothesis that will be tested is whether hypocrisy induction had any effect in reducing plagiarism. We addressed the limitation of the previous study, which was the lack of objective plagiarism measurement and the likelihood that participants' academic behavior was influenced by other activities other than the experiment. Moreover, we filled the research gap as most studies on hypocrisy induction have been in the context of health or environmental-friendly behavior (Dickerson et al., 1992; Fried \& Aronson, 1995a; Gamma, Mai, \& Loock, 2020; J. Stone et al., 1994a). Methodologically, the study contributes to the body of literature on the implementation of cognitive dissonance principle in modifying behavior, specifically academic dishonesty. 


\section{Method}

Participants.

The study took place in a public high school in Jakarta, Indonesia. The principal has previously reported rampant plagiarism among the students. The school had placed rules in order to discourage students from plagiarizing. However, no students have been punished despite the many reports of plagiarism. The students in the school were categorized into three grades, as customary in all high schools in Indonesia. After much deliberation with the school's authority, the first-year students and third-year students were opted out of the study. First-year students did not have many writing assignments, which would make it difficult to measure plagiarism. At the time of the study, third-year students were busy with preparation for the national exam. Thus, only second-year students were offered participation in the study. Of the 136 participants, all were in their second year of high school and aged between 15 to 17 in this study. 84 participants were male and the other 52 were female.

\section{Instruments}

Plagiarism rate. All participants were assigned to write an essay on four options of topic: (I) the curriculum changes in Indonesia, (2) screening process for congressional candidates with criminal records, (3) improving educational quality in Indonesia, and (4) the ideal qualities of a leader for Jakarta. The participants were instructed that the essay must include a central thesis regarding a chosen topic, arguments supporting said thesis, and a conclusion reiterating the thesis. All topics were chosen to incite participants' personal opinion (an original writing) while requiring them to search for facts supporting their views (as a temptation to copy or plagiarize). The assignment was given by a teacher, thus giving the impression that it was not connected with the plagiarism study. The participants were given a day to finish the assignment, to ensure that participants have a chance to use their home computer and search for information on the internet. These factors along with the choices of topic give participants the chance to plagiarize. Collected assignments were checked for similarity using a software called PlagScan, which compares the essays to other writings on the internet. A similarity percentage of 0 meant no part of the essay was found to be similar with other writings on the internet. The highest possible score is 100 , meaning all parts of the essay contained writings found on the internet. The similarity percentage for each essay was used as plagiarism rate. 
Plagiarism attitude scale. Plagiarism attitude was measured using a self-report questionnaire. We developed a plagiarism attitude scale based on similar items used in a plagiarism research by Mavrinac, Brumini, Bilić-Zulle, \& Petrovečki (20l0). The items were selected, translated, and five additional items were added into the final questionnaire to enhance its compatibility with Indonesian culture. The final questionnaire consists of 8 items: 3 items measure general attitude toward plagiarism, 2 items measure peer perception toward plagiarism, and 3 items measure school's perceived norms on plagiarism offenses. Students rate their attitudes and behavior on a 4-point Likert scale, ranging from 'highly disagree' to 'highly agree'. The plagiarism attitude scale generates three subscales scores and an overall total score. The General Attitude subscale scores may range from 3 to 12 and measures the level of disapproval toward plagiarizing itself. Peer Perception subscale scores range from 2 to 8 and measure subjective peer norms, specifically the perceived level of peer's disapproval toward plagiarism. Lastly, the School Norm subscale range from 3 to 12 and measures the subjective norm upheld by the school. Higher total score on the plagiarism attitude scale indicates more disapproval toward plagiarism. Corrected item-total correlation analysis showed moderate validity ranging from .22 to .58 . A reliability test was conducted to reveal the scale had an alpha coefficient of 0.72 , which indicated high internal consistency(Spector, 1992).

Table I

Sample items on the plagiarism attitude scale

\begin{tabular}{|c|c|}
\hline & Sample item \\
\hline $\begin{array}{l}\text { Attitude toward } \\
\text { plagiarism }\end{array}$ & $\begin{array}{l}\text { Students who have just started learning scientific writing } \\
\text { should only receive lighter punishments for plagiarism. }\end{array}$ \\
\hline $\begin{array}{l}\text { Peer perception } \\
\text { toward plagiarism }\end{array}$ & My friends plagiarized without being found out. \\
\hline $\begin{array}{l}\text { School's perceived } \\
\text { norm }\end{array}$ & $\begin{array}{l}\text { In my school, students who were caught plagiarizing } \\
\text { received harsh punishment. }\end{array}$ \\
\hline
\end{tabular}

Plagiarism knowledge. The participants' knowledge of plagiarism was measured using a 10item test adapted from a plagiarism tutorial created by the University of Southern Mississippi (University of Southern Mississippi, n.d.). The test was adapted into Indonesian. An analysis of item difficulty generated from the participants' ranged from 0.33 to 0.72 . The 
range indicated the test had an appropriate variation of difficulty level (Cohen \& Swerdlik, 2010).

Table 2

Sample items on the plagiarism knowledge scale

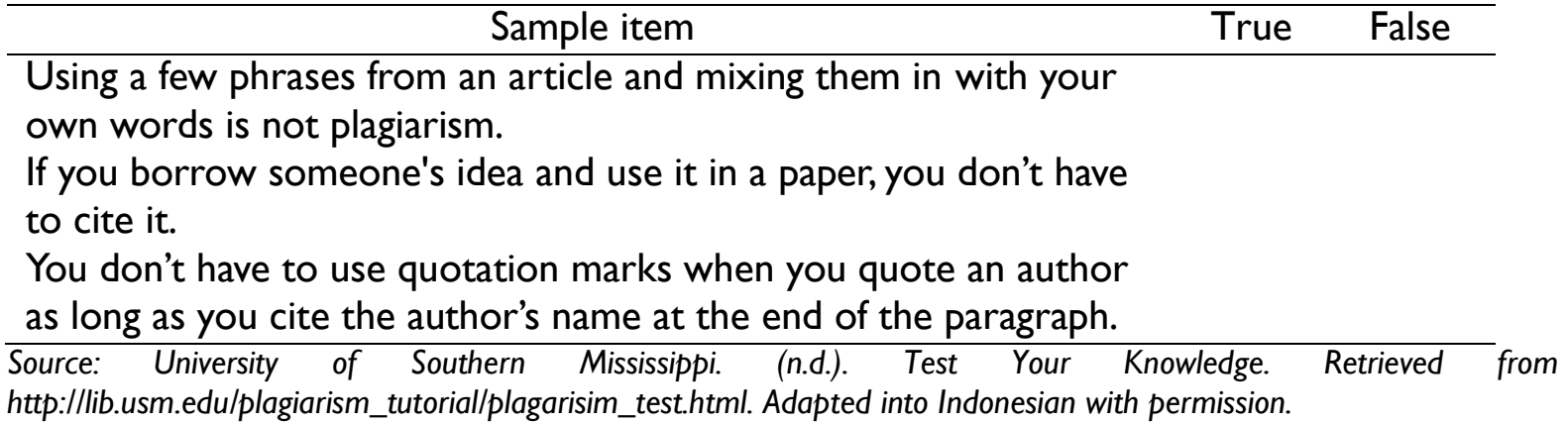

Procedure

Cognitive dissonance happened when an individual was reminded that his/her action does not align with what he/she is promoting (Aronson et al., 2016) In order to experience a feeling of hypocrisy, an individual has to a) advocate for something and b) be aware of what he/she actually does. Therefore, in this study we induce hypocrisy by manipulating two variables: commitment (where participants are asked to advocate against plagiarism) and mindfulness (where participants are reminded that they have plagiarized in the past). Using a $2 \times 2$ factorial design, we randomized participants into four condition groups (see Table I). We previously obtained a list of all the second-year students and randomly assigned each student to one of the four condition groups. This was done to ensure smooth and concise instruction during the day of the experiment. 
Table 3

$2 \times 2$ Experiment Matrix

\begin{tabular}{cll}
\hline Mindfulness & \multicolumn{1}{c}{ Commitment } & \multicolumn{1}{c}{ Without commitment } \\
\hline & $\begin{array}{l}\text { Listing past situations in } \\
\text { which they have plagiarized } \\
\text { and signing an anti- } \\
\text { plagiarism poster (hypocrisy } \\
\text { condition) }\end{array}$ & $\begin{array}{l}\text { Only listing past situations in } \\
\text { which they have plagiarized } \\
\text { (mindful condition) }\end{array}$ \\
$\begin{array}{c}\text { Without } \\
\text { mindfulness }\end{array}$ & $\begin{array}{l}\text { Only signing an anti- } \\
\text { plagiarism poster } \\
\text { (commitment condition) }\end{array}$ & Control group \\
\hline
\end{tabular}

In-class manipulation took place at the end of a school day in the students' own classroom. The school had six classrooms of second-year students, and each class had 30 to 35 students. There were four rows of seats in each classroom, and each row consisted of five long benches made for two students. Thus, one classroom may fit 40 individual seats. On the day of the experiment, one research assistant was assigned to each classroom. Firstly, homeroom teachers of each class introduced the research assistant and the general purpose of the research. The teachers also explained that participating in the research may give the students the opportunity to see how a scientific study is conducted. After the introduction, the teachers left the classroom for the remaining of the day to ascertain the students that their participation would not affect their school grades in any way. Then, the research assistant greeted the students, introduced themselves and reminded the students that participation was optional. All students opted to stay and participate in the experiment.

The students were then asked to sit at the row in which members of their condition group were seated, according to the previously arranged condition assignment. The seating arrangement for each class is depicted in Figure I. Once the participants were in their assigned condition, the research assistant read the general instruction for the experiment and distributed the appropriate materials for each condition. All materials contained an informed consent which the participants were required to sign and specific instructions for the conditions that they were assigned. 


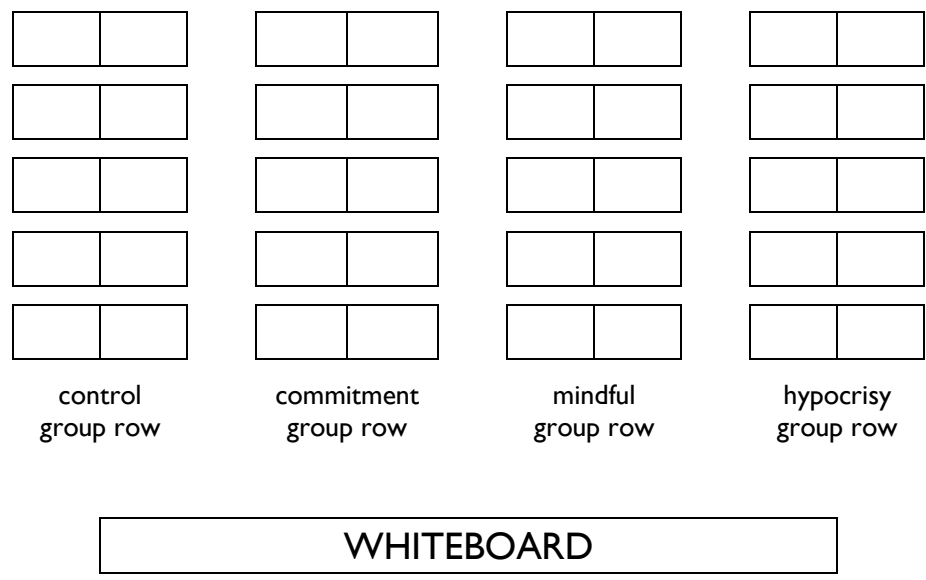

Figure I. Seating arrangement for each experimental group

The procedure was a replication of the study conducted by Goldonowicz (20I4). Changes were made to address the limitation of the previous research. In the Goldonowicz study, students were asked to report their cheating behavior using a self-report questionnaire. The participants were assured that their answers would be confidential, but this method made participants more prone to social desirability bias. Since cheating was perceived as undesirable behavior, they would be less likely to be honest. In this study, the measurement of plagiarism was done using a similarity rate in the assignments submitted by the students. This method allowed us to measure plagiarism more objectively while still giving participants the opportunity to cheat.

The previous study measured dishonest academic behavior one month after the manipulation was done. While the time-lapse allowed participants the opportunity to cheat, there was concern that participants would have had forgotten how many times they cheated during the one-month period. Moreover, longer time-lapse also increase the likelihood that participants' academic behavior was influenced by other activities other than the experiment. Therefore, we shorten the time lapse between the experiment to the measurement of plagiarism to one week.

In giving out the assignments, we coordinated with the Indonesian language teacher, which was the subject that had the most writing assignment. A week after the in-class manipulation, the Indonesian language teacher gave the instruction of the assignment as part of a school lesson. The students were asked to write an expository article about one out of four selectable topics, in which they would need to present some facts relating to 
the topic and state a supporting or opposing argument. The assignment was designed to give the students the opportunity to plagiarize by instructing students to search for information from the internet and write the article at home. The students' submitted assignments were put into the PlagScan software, which compares the writings with online sources. Each writing would get a similarity score based on the comparison. The similarity score was used as the plagiarism rate. Thus higher similarity scores indicate higher amount of plagiarized content.

\section{Result}

This study used $2 \times 2$ factorial design to test the difference between the four condition groups on the plagiarism rate. Almost all participants were found to have committed some amount of plagiarism (Table 2). A two-way analysis of variance was conducted on the influence of commitment (where participants are asked to advocate against plagiarism) and mindfulness (where participants are reminded that they have plagiarized in the past) on plagiarism rate. All effects were statistically insignificant at the .05 significance level. The main effect for commitment yielded an $F$ ratio of $F(I, I 32)=.049, p=.825, \omega^{2}=.007$. While the main effect for mindfulness yielded an $\mathrm{F}$ ratio of $\mathrm{F}(\mathrm{I}, \mathrm{I32})=.107, p=.744, \omega^{2}=.006$. The interaction between those two variables also yielded a statistically insignificant result. Thus, the result of the main effect analysis indicated no significant effect of hypocrisy induction in reducing plagiarism among the participants (Figure 2).

Table 4

Median and standard deviations for each condition groups

\begin{tabular}{lccc} 
Condition group & $\mathrm{N}$ & \multicolumn{2}{c}{ Plagiarism rate } \\
\cline { 2 - 4 } & & Median & SD \\
\hline Hypocrisy & 34 & 85.8 & 25.8 \\
Commitment & 34 & 88.8 & 31.5 \\
only & & & \\
Mindful only & 30 & 84.4 & 26.85 \\
Control & 38 & 85.5 & 24.66 \\
\hline
\end{tabular}




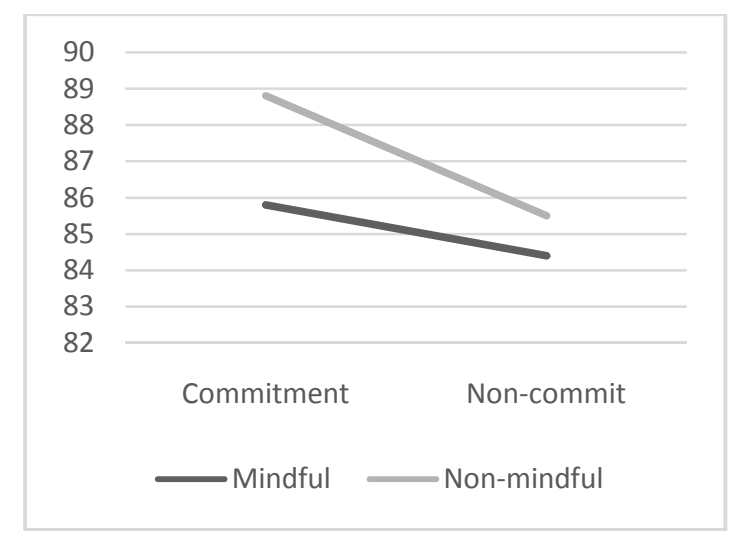

Figure 2. Graph of median plagiarism rate among the four condition groups

The central tendency in Table 2 showed the plagiarism score of participants in each condition group. All medians were above 80 , suggesting a high similarity percentage between the participants' essays and other writings on the internet. This indicates that the majority of participants' essays contained plagiarism, regardless of experimental condition. This was supported by the plagiarism score distribution in Figure 3. 32\% of participants had a plagiarism score ranging from 91 to 100 , indicating their submitted essay was highly similar to other writings on the internet. The second-highest amount of participants was found in the 81 to 90 score range, which showed $29 \%$ of the participants' essays contained only a small amount of independent writing. This score distribution showed that plagiarism was rampant among the participant, notwithstanding the experimental treatment they were given.

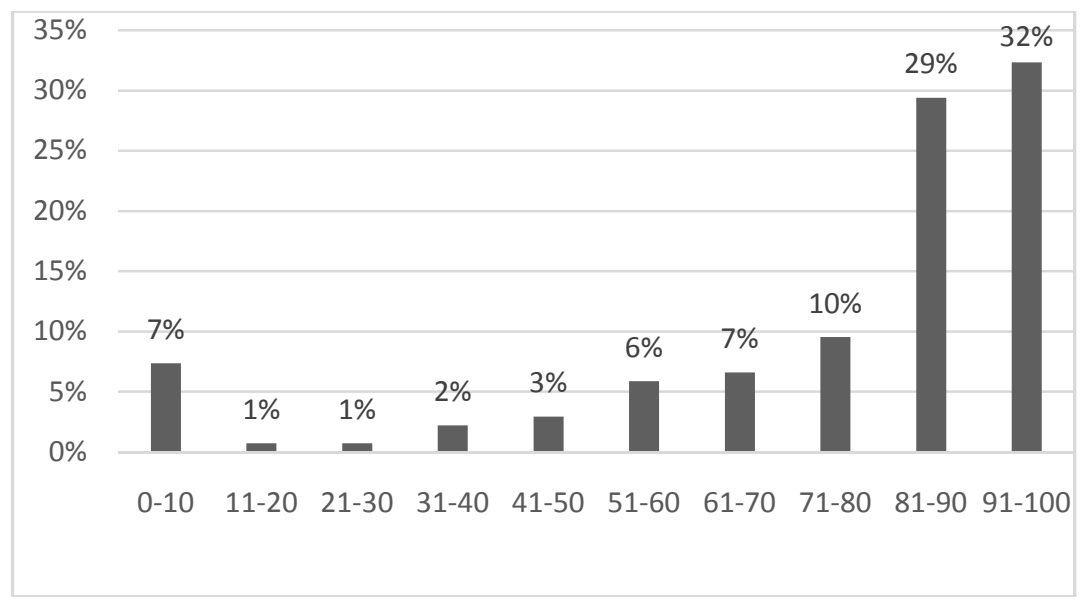

Figure 3. Plagiarism score distribution 
Out of 136 participants, 68 students filled the plagiarism attitude scale (the participants in the hypocrisy induction group and mindful condition group). Score distribution on the plagiarism attitude scale showed that the majority of participants have a neutral attitude toward plagiarism (see Table 3). This indicates that while they do not condone plagiarism, they perceived it as a justifiable act in certain cases. Closer analysis on the dimensional scale supported this finding. Only 12\% ( $9 \%$ high score, 3\% higher than average) participants perceived their peer members as being disapproval toward plagiarism. On the school norm subscale, only $13 \%$ of participants ( $4 \%$ high score, $9 \%$ higher than average score) felt the school strictly uphold the rules preventing plagiarism. Thus, scores on the peer perception and school norm scale showed more participants felt plagiarism would yield severe social punishment from neither their friends nor their teachers.

Table 5

Total and dimensional plagiarism attitude scale categorization

\begin{tabular}{lcc}
\hline \multicolumn{1}{c}{ Score categorization } & $\mathrm{N}$ & $\%$ \\
\hline Total score & $\mathrm{I}$ & $1 \%$ \\
High & 12 & $18 \%$ \\
Above average & 48 & $71 \%$ \\
Average & 7 & $10 \%$ \\
Lower average & 0 & - \\
Low & & \\
General attitude & 0 & - \\
High & 8 & $12 \%$ \\
Above average & 57 & $84 \%$ \\
Average & 3 & $4 \%$ \\
Lower average & 0 & - \\
Low & & \\
Peer perception & 6 & $9 \%$ \\
High & 2 & $3 \%$ \\
Above average & 59 & $87 \%$ \\
Average & 0 & - \\
Lower average & 1 & $1 \%$ \\
Low & & \\
School norm & 3 & $4 \%$ \\
High & 6 & $9 \%$ \\
Above average & $72 \%$ \\
Average & 49 & $13 \%$ \\
Lower average & 9 & $1 \%$ \\
Low & 1 & \\
\hline & & \\
\hline & &
\end{tabular}

The 68 students who filled out the plagiarism attitude scale were also given a plagiarism knowledge test. The test measured participants' knowledge regarding plagiarism using 10 true/false items. Scores on the plagiarism knowledge test indicate the participants had moderate knowledge about plagiarism. As presented in Table 4, the highest percentage of 
participants (35\%) achieved a 5 out of 10 scores on the plagiarism knowledge test. Meanwhile, no participants were able to achieve a full score on the test. This result indicates that the participants only had moderate knowledge of plagiarism, possibly contributing to the substantial level of plagiarism.

Table 6

Percentage of participants on each possible plagiarism knowledge score

\begin{tabular}{ccc}
\hline Score & N & $\%$ \\
\hline 10 & 0 & - \\
9 & 0 & - \\
8 & 1 & $1 \%$ \\
7 & 6 & $9 \%$ \\
6 & 16 & $24 \%$ \\
5 & 24 & $35 \%$ \\
4 & 11 & $16 \%$ \\
3 & 8 & $12 \%$ \\
2 & 1 & $1 \%$ \\
1 & 1 & $1 \%$ \\
\hline
\end{tabular}

\section{Discussion}

In this study, we attempted to use the cognitive dissonance principle in reducing academic dishonesty, specifically plagiarism. We addressed the limitations of the previous study through using an objective measurement of plagiarism, using a similarity detecting program. However, high plagiarism rate was found on more than $50 \%$ of participants, which indicate most of the participant plagiarized in spite of different experimental treatment. Statistical analysis on the plagiarism rate among the four condition groups showed no significant effect of hypocrisy induction in reducing plagiarism among the participants. This result may be affected by the plagiarism rate score, which formed a negatively skewed distribution.

Previously, hypocrisy induction has been successfully implemented as a behavioral modification technique (Aronson et al., 1991; Dickerson et al., 1992; Stone et al., 1994). However, a study has shown that a person may justify their behavior instead of changing it to reduce their cognitive dissonance (McGrath, 2017). Moreover, higher dependence on behavior was related to the increased likelihood of using self-exempting beliefs to reduce 
dissonance (Kleinjan, van den Eijnden, \& Engels, 2009). Based on the substantial amount of plagiarism found in the participants' assignment, it could be inferred that their high dependence on plagiarism led to justification rather than behavioral change. As one student wrote on an anti-plagiarism poster as part of the study, "Doing this (campaigning against plagiarism) is useless, people will still cheat!” (“Nggak ada gunanya bikin ginian, bakal tetep nyontek juga!').

Further analysis of dimensional scores revealed that the majority of participants viewed their peers, and the schools also held neutral attitude plagiarism. Thus, the neutral attitude on plagiarism could also be attributed to the subjective norm perceived by participants. Previous study has confirmed that the perception of school climate was related to academic dishonesty (Fitria, 2019). The school in which the study was conducted had anti-plagiarism rules. However, the extent to which the rules were socialized, articulated, and upheld by the school might affect participants' neutral attitude on plagiarism. Moderate score on the two subscales indicates the participants do not expect to receive harsh social punishment after committing plagiarism.

The role of social norm in this study also supports the theory of normative social behavior, which studied how descriptive norms influence behavioral intentions (Rimal \& Real, 2005). This theory has been applied in the context of academic misconduct by Henningsen \& Henningsen (2020). Students may be aware of the harmful nature of plagiarism, but seeing their peer cheat would motivate students to match their behavior with their surroundings. This would also explain the ubiquitous nature of plagiarism we found in the present study.

The majority of participants only had moderate knowledge regarding plagiarism, possibly contributing to the ample amount of plagiarism. On top of the plagiarism knowledge questionnaire, participants were asked to write their own definitions of plagiarism. Word count analysis showed that almost all participants used the word "copy" in their definition. This finding further indicates a shallow understanding of plagiarism, which was perceived as "copying" exactly from other sources. It also explains why no participant managed to receive a full score on the plagiarism knowledge test. It is most likely that participants do not differentiate different types of plagiarism, thus may unintentionally plagiarize in their submitted assignment. 
Reflecting on the fact that some form of plagiarism may be unintentional, lack of knowledge regarding plagiarism may contribute to the neutral attitude toward plagiarism. In Indonesia, plagiarism is rarely included in the formal curriculum. Score distribution on the plagiarism knowledge test showed students' lack of understanding of the concept of intellectual property. Thus, they may perceive the process of 'copying and pasting' is a way of collecting information instead of stealing someone's intellectual property. Previous study by Ukpebor \& Ogbebor (2013) supported this finding that lack of awareness in plagiarism contributes to a relaxed attitude toward plagiarism as unethical behavior.

The present study has some limitation. Only one high school was involved in the study, in which plagiarism was rampant and not viewed as a serious offense. Reflecting on the result of this study, student's dependence on plagiarism might have made rationalization more likely to happen than behavioral change. If this experiment is conducted in another school with a different academic climate, it could lead to a different result. Therefore, the result of this study would be difficult to generalize.

\section{Conclusion}

Based on these results, we conclude that high dependence on plagiarism caused the participant to justify rather than change their behavior. While the experiment managed to induce a feeling of hypocrisy, it might have driven participants to use external justification (such as the school's ignorance) even more. Other than school climate, peer perception, and moderate knowledge regarding plagiarism may contribute to the persisting evidence of plagiarism. This study also addressed the limitation of previous studies in plagiarism by using an objective measurement and found an overwhelmingly high plagiarism rate among participants. This result reflects the banality of plagiarism and the use of justification to reduce cognitive dissonance.

\section{References}

Amin, J. N. (2016). Redefining the role of teachers in the digital era. The International Journal of Indian Psychology, 3(3), 40-45. https://doi.org/I8.0I.I0I/20160303

Arda, A., Saehana, S., \& Darsikin, D. (20I5). Pengembangan Media Pembelajaran Interaktif 
Berbasis Komputer Untuk Siswa Smp Kelas VIII. E-Jurnal Mitra Sains, 3(I), 69-77.

Aronson, E. (1999). The power of self-persuasion. American Psychologist, 54(I I), 875-884. https://doi.org//0.1037/h0088/88

Aronson, E., Fried, C., \& Stone, J. (199I). Overcoming denial and increasing the intention to use condoms through the induction of hypocrisy. American Journal of Public Health, 8I(I2), I636-1638. https://doi.org/I0.2105/AJPH.8I.12.1636

Aronson, E., Wilson, T. D., Akert, R. M., \& Sommers, S. R. (20I6). Social Psychology (9th ed.). London: Pearson Education.

Burdick, T. (1998). Pleasure in information seeking: reducing information aliteracy. Emergency Librarian, 25(3), I3-17.

Cohen, R. J., \& Swerdlik, M. (2010). Psychological Testing and Assessment: An Introduction to Tests and Measurement (7th ed.). McGraw-Hill Primis.

Dickerson, C. A., Thibodeau, R., Aronson, E., \& Miller, D. (1992). Using cognitive dissonance to encourage water conservation. Journal of Applied Social Psychology. United Kingdom: Blackwell Publishing. https://doi.org/I0.IIII/j.I559-I8I6.1992.tb00928.x

Fitria, Y. (2019). Perilaku menyontek: Persepsi terhadap iklim sekolah dengan ketidakjujuran akademik. Jurnal IImiah Psikologi Terapan, I(I), I-I2. https://doi.org/l0.22219/jipt.v7il.7833

Fitriyadi, H. (20I3). Integrasi Teknologi Informasi Komunikasi Dalam Pendidikan $\square$ : Potensi Manfaat, Masyarakat Berbasis Pengetahuan, Pendidikan Nilai , Strategi Implementasi Dan. Jurnal Pendidikan Teknologi Dan Kejujuran, 2 I (3), 269-284.

Fried, C. B., \& Aronson, E. (1995a). Hypocrisy, Misattribution, and Dissonance Reduction. Personality and Social Psychology Bulletin, 2 I (9), 925-933. https://doi.org/I0.1 I77/0146/67295219007

Fried, C. B., \& Aronson, E. (1995b). Hypocrisy, Misattribution, and Dissonance Reduction. Personality and Social Psychology Bulletin, 2 I (9), 925-933. https://doi.org/I0.1 I77/0|46/67295219007

Gamma, K., Mai, R., \& Loock, M. (2020). The Double-Edged Sword of Ethical Nudges: Does Inducing Hypocrisy Help or Hinder the Adoption of Pro-environmental Behaviors? Journal of Business Ethics, I6 I (2), 35I-373. https://doi.org/I0.1007/s I055I-0 I8-3930-2

Germek, G. (20I2). The Lack of Assessment in the Academic Library Plagiarism Prevention Tutorial. College \& Undergraduate Libraries, 19(I), I-17. https://doi.org//0.1080/1069/316.2012.652547

Goldonowicz, J. M. (20I4). Cognitive Dissonance in the Classroom: the Effects of Hypocrisy on Academic Dishonesty. University of Central Florida.

Harding, T. S., Mayhew, M. J., Finelli, C. J., \& Carpenter, D. D. (2007). The Theory of Planned Behavior as a Model of Academic Dishonesty in Engineering and Humanities Undergraduates. Ethics \& Behavior, 17(3), 255-279. https://doi.org// 0.1080/10508420701519239

Heckler, N. C., \& Forde, D. R. (2015). The Role of Cultural Values in Plagiarism in Higher Education. Journal of Academic Ethics, I3(I), 6I-75. https://doi.org/10.1007/s I0805-0 I49221-3

Henningsen, M. L. M., \& Henningsen, D. D. (2020). Cheating, Pluralistic Ignorance, and the 
Theory of Normative Social Behavior. Southern Communication Journal, 85(I), I6-27. https://doi.org/10.1080/1041794X.2019.1678195

Hoda, B. (2017). The flipped classroom model: when technology enhances professional skills. The International Journal of Information and Learning Technology, 34(I), 51-62. https://doi.org// 0.1 108/IJILT-07-2016-0025

Hopson, M. H., Simms, R. L., \& Knezek, G. A. (200I). Using a Technology-Enriched Environment to Improve Higher-Order Thinking Skills. Journal of Research on Technology in Education, 34(2), I09-119. https://doi.org/I0.1080/1539/523.2001.10782338

Igo, L. B., Bruning, R., \& McCrudden, M. T. (2005). Encoding disruption associated with copy and paste note taking. In L. M. PytlikZillig, M. Bodvarsson, \& R. Bruning (Eds.), Technology-Based Education: Bringing Researchers and Practitioners Together (pp. I07-I 19). Information Age Publishing. Retrieved from http://apps.isiknowledge.com.proxy.lib.sfu.ca/full_record.do?product=WOS\&search_mo $\mathrm{de}=$ GeneralSearch\&qid= I \&SID = I FLhNmjcGEMIBdfoKbB\&page $=\mid$ \&doc $=4 \&$ cacheurIFro mRightClick=no

Keith-Spiegel, P., \& Whitley, B. E. (200I). Introduction to the special issue. Ethics \& Behavior, I I (3), 2 I 7-2 I8. https://doi.org/I0.I207/SI 53270 I9EBI I03_I

Khotimah, S. K., Fadhli, M. I., \& Habibi, Y. (2017). Meningkatkan Kejujuran Akademik : Efektivitas Classroom Developmental Bibliotherapy Dalam Pembelajaran. Humanitas, I4(2), 90-102.

Kleinjan, M., van den Eijnden, R. J. J. M., \& Engels, R. C. M. E. (2009). Adolescents' rationalizations to continue smoking: The role of disengagement beliefs and nicotine dependence in smoking cessation. Addictive Behaviors, 34(5), 440-445. https://doi.org//0.1016/j.addbeh.2008.12.010

Kustiwi, N. (20/4). Motivasi dan perilaku plagiat di kalangan siswa SMA: Persepsi siswa terhadap perilaku plagiat dan motivasi siswa dalam melakukan tindak plagiat di kalangan siswa SMA Cita Hati Surabaya. Jurnal Universitas Airlangga, 3(3), 569-587.

Lai, C., Yeung, Y., \& Hu, J. (20I6). University student and teacher perceptions of teacher roles in promoting autonomous language learning with technology outside the classroom. Computer Assisted Language Learning, 29(4), 703-723. https://doi.org/I0.1080/0958822I.2015.101644 I

Lines, L. (2016). Substantive editing as a form of plagiarism among postgraduate students in Australia. Assessment \& Evaluation in Higher Education, 4I (3), 368-383. https://doi.org/10.1080/02602938.2015.1013919

Marshall, S., \& Garry, M. (2005). How well do students really understand plagiarism? In ASCILITE 2005 - The Australasian Society for Computers in Learning in Tertiary Education (Pp. 457-467).

Mavrinac, M., Brumini, G., Bilić-Zulle, L., \& Petrovecki, M. (20I0). Construction and validation of attitudes toward plagiarism questionnaire. Croatian Medical Journal, 5 I (3), 195-20I. https://doi.org/I0.3325/cmj.2010.5I.195

McGrath, A. (2017). Dealing with dissonance: A review of cognitive dissonance reduction. Social and Personality Psychology Compass, II (I2), I-I7. https://doi.org/I0.1 I I I/spc3.12362

Mediani, M. (20I8, August 2I). Mendikbud Minta Internet Cepat untuk Sekolah Disegerakan. 
Retrieved from https:/www.cnnindonesia.com/nasional/2018082 I075629-20323794/mendikbud-minta-internet-cepat-untuk-sekolah-disegerakan

Mudiahardjo, R., \& Donny, B. (2009). Review of individual economies: ICT-related education and capacity-building programs. In Digital Review of Asia Pacific 2009-20 I0. Montreal: SAGE Publications Inc.

Neville, C. (20I0). Complete Guide to Referencing and Avoiding Plagiarism (2nd Edition) (2nd ed.). McGraw-Hill. Retrieved from http://site.ebrary.com/lib/colpos/docDetail.action?doclD= 10404007

O’Rourke, J., Barnes, J., Deaton, A., Fulks, K., Ryan, K., \& Rettinger, D. A. (2010). Imitation is the sincerest form of cheating: The influence of direct knowledge and attitudes on academic dishonesty. Ethics \& Behavior. Rettinger, David A.: University of Mary Washington, I30I College Avenue, Fredericksburg, VA, US, 2240I, dretting@umw.edu: Taylor \& Francis. https://doi.org//0.1080//05084209034826/6

Ozdamli, F., \& Asiksoy, G. (2016). Flipped Classroom Approach. World Journal on Educational Technology, 8(2), 98. https://doi.org/10.18844/wjet.v8i2.640

Park, C. (2004). Rebels without a clause: towards an institutional framework for dealing with plagiarism by students. Journal of Further and Higher Education, 28(3), 29I-306. https://doi.org// 0.1080/0309877042000241760

Permanasari, I. (2015, March 17). Digitalisasi dan Dunia Pendidikan. Retrieved from http://print.kompas.com/baca/2015/03//7/Digitalisasi-dan-Dunia-pendidikan

Razera, D. (20I I). Awareness, Attitude and Perception of Plagiarism Among Students and Teachers At Stockholm University. Stockholm University.

Rimal, R. N., \& Real, K. (2005). How Behaviors are Influenced by Perceived Norms: A Test of the Theory of Normative Social Behavior. Communication Research, 32(3), 389-4I4. https://doi.org// 0.1 I 77/0093650205275385

Shelton, C. C., Archambault, L. M., \& Hale, A. E. (2017). Bringing Digital Storytelling to the Elementary Classroom: Video Production for Preservice Teachers. Journal of Digital Learning in Teacher Education, 33(2), 58-68. https://doi.org//0.1080/21532974.2016.127687|

Spear, J. A., \& Miller, A. N. (20I2). The Effects of Instructor Fear Appeals and Moral Appeals on Cheating-Related Attitudes and Behavior of University Students. Ethics \& Behavior, 22(3), 196-207. https://doi.org//0.1080/10508422.2012.659603

Spector, P. E. (1992). Summated rating scale construction: An introduction. Summated Rating Scale Construction: An Introduction. Thousand Oaks, CA, US: Sage Publications, Inc. https://doi.org/I0.4I35/978|4I2986038

Stone, J., Aronson, E., Crain, A. L., Winslow, M. P., \& Fried, C. B. (1994a). Inducing Hypocrisy as a Means of Encouraging Young Adults to Use Condoms. Personality and Social Psychology Bulletin, 20(I), I16-128. https://doi.org/I0.1 I77/0146/67294201012

Stone, J., Aronson, E., Crain, A. L., Winslow, M. P., \& Fried, C. B. (I 994b). Inducing Hypocrisy as a Means of Encouraging Young Adults to Use Condoms. Personality and Social Psychology Bulletin, 20(I), I I6-128. https://doi.org/I0.1 I77/0 I46I67294201012

Stone, W. (2000). A New Culture of Teaching for the 2 I st Century. In D. T. Gordon (Ed.), The Digital Classroom: How Technology Is Changing The Way We Teach and Learn.

Sureda-Negre, J., Comas-Forgas, R., \& Oliver-Trobat, M. F. (20I5). Academic plagiarism 
among secondary and high school students: Differences in gender and procrastination. Comunicar, 22(44), I03-III. https://doi.org/I0.39I6/C44-20I5-II

Ukpebor, C. O., \& Ogbebor, A. (2013). Internet and plagiarism: Awareness, attitude and perception of students of secondary schools. International Research: Journal of Library \& Information Science, 3(2), 254-267. https://doi.org/I0.1017/CBO978I I074I5324.004

Ungusari, E. (2015). Kejujuran dan ketidakjujuran akademik pada siswa SMA yang berbasis agama. Universitas Muhammadiyah Surakarta. https://doi.org/I0.1377/hlthaff.20I3.0625

University of Southern Mississippi. (n.d.). Plagiarism tutorial: Test your knowledge. Retrieved March 25, 2019, from http://lib.usm.edu/plagiarism_tutorial/plagarisim_test.html

Vinski, E. J., \& Tryon, G. S. (2009). Study of a Cognitive Dissonance Intervention to Address High School Students' Cheating Attitudes and Behaviors Study of a Cognitive Dissonance Intervention to Address High School Students' Cheating Attitudes and Behaviors. Ethics \& Behavior, 19(3), 218-226. https://doi.org// 0.1080/10508420902886692

Whitley, B. E. (1998). Factors associated with cheating among college students: A review. Research in Higher Education, 39(3), 235-274. https://doi.org/I0.1023/A: I0I8724900565

Zalnur, M. (2012). Plagiarisme Di Kalangan Mahasiswa Dalam Membuat Tugas-Tugas Perkuliahan Pada Fakultas Tarbiyah lain Imam Bonjol Padang. Al-Ta’lim, I9(I), 55-66. https://doi.org/I0.I5548/jt.v19il.6 